\title{
Root mass of grass swards in different grazing systems
}

\author{
B. Deinum
}

Department of Field Crops and Grassland Science, Agricultural University, Wageningen, Netherlands

Accepted: 3 October 1985

Key words: root production, tillering, root decomposition, grazing, carbon balance

\section{Summary}

In order to complete the carbon balance of grazed swards, dynamics of root mass were measured of well fertilized $L$. perenne dominated swards either grazed rotationally or continuously with steers.

Contrary to results from the literature, root mass increased considerably under continuous grazing, compared to rotational grazing. This was associated with increased tillering. It is explained that management systems that favour tillering under lax defoliation will also favour root production.

Conditions that favour soil organisms will stimulate decomposition of dead roots and so decline total root mass. From the great changes in root mass it was suggested that about $27 \%$ of gross photosynthesis or about $80 \mathrm{~kg}\left(\mathrm{CH}_{2} \mathrm{O}\right)$ per ha is used daily for growth and maintenance respiration of roots and that up to $50 \mathrm{~kg} / \mathrm{ha}$ of dead root mass can be decomposed daily.

\section{Introduction}

Recent investigations in north-west Europe have revealed that dairy production is similar under rotational grazing and continuous grazing (Ernst et al., 1980). These findings have stimulated further research on herbage production and physiology of swards when grazed by either system. Results have shown that seasonal crop photosynthesis is similar or somewhat smaller under continuous grazing than under rotational grazing (Deinum et al., 1981). Lantinga (1985) later found that maintenance respiration is smaller under continuous grazing. These findings on photosynthesis, respiration and animal production suggest that more assimilates remain above grazing height and less is translocated to the roots under continuous grazing. This would be in line with earlier findings that root mass is smaller under frequent cutting like in lawns.

In order to complete the carbon balance a programme was developed to study root mass of swards under grazing and this paper summarizes the information. 


\section{Literature}

Several rather basic aspects are important with regard to root production of grass swards. Almost every tiller can be considered as an individual plant with its own root system, even when the connection between mother and daughter tiller is still functioning. Then root mass and tiller density might be correlated.

During growth, a grass tiller increases in weight both of shoot and root, in some kind of functional equilibrium. When the tiller is defoliated, the plant tries to restore the shoot and stops root growth until the original equilibrium between shoot and root has been restored (Brouwer, 1962). This indicates that with the periodically heavy defoliations occurring under rotational grazing root mass might remain rather low. The more frequent the defoliations and the lower the cutting height, the lower the root mass (Troughton, 1957; Klapp, 1954).

External conditions affect the distribution of assimilates over shoot and root, e.g. root growth lags behind shoot growth at low light intensity and high temperature. The reverse is true when mineral supply is limited. Root growth is also reduced when tillers are in the reproductive phase (Troughton, 1978). Therefore seasonal patterns of root production may be expected from the seasonal pattern of tillering and of external conditions. Troughton (1982) has also measured the average lifespan of roots of some grasses under defoliation and found in Lolium perenne an average lifespan of $191 \pm 18$ days, suggesting that root mass is turned over between once and twice a year. Similarly, the lifespan of tillers of $L$. perenne is about 180 190 days according to the results of Davies et al. (1974). Studies on production have revealed that gross photosynthesis of well managed swards reaches about 60 tonnes $\left(\mathrm{CH}_{2} \mathrm{O}\right)$ per ha per year, $10 \%$ of which is assumed to be used for root production (Parsons et al., 1983) resulting in a dry-matter production of about 4 tonnes ha-1 year $^{-1}$.

This annual production of some 4 tonnes root mass per ha also indicates that in steady state conditions an equal amount is decomposed annually. It may be expected that the rate of decomposition is affected by soil aeration, soil-water content, temperature and the nutrient supply to the soil organisms.

Therefore a seasonal pattern may be expected, both in root production and in decomposition but it is not at all clear how root mass changes during the season, how it is affected by grazing systems and how much of the gross photosynthesis is used for the roots.

\section{Material and methods}

Root masses were measured regularly of swards grazed either rotationally or continuously in 1980 and 1981. Grazing was done by 1.5 -year old steers. In continuous grazing average sward height (including dung patches) was maintained at $7-8 \mathrm{~cm}$. Rotational grazing consisted of 3 days of grazing followed by 3-4 weeks of regrowth. Stocking rates were similar in both grazing systems. Nitrogen fertilization was about $400 \mathrm{~kg} \mathrm{ha}^{-1}$ year $^{-1}$. Paddocks were about 1 ha each. The soil was a moist sandy soil covered with a Lolium perenne dominated sward that was grazed and cut 
rotationally in the previous year.

Trials were carried out in 1980 and in 1981 on separate fields.

Root samples of the 1980 trial were taken on 2 April, before grazing started and on 18 June, 3 September, 28 October 1980 and 6 April 1981. In the 1981 trial samples were taken on 8 April, 10 June, 3 September, 4 November 1981 and 2 March 1982.

At sampling soil cores of $40 \mathrm{~cm}^{2}$ were taken from the top $30 \mathrm{~cm}$ of the soil and separated into $0-10 \mathrm{~cm}, 10-20 \mathrm{~cm}$ and $20-30 \mathrm{~cm}$ fractions. Forty samples were taken per field and per sampling date to arrive at acceptable standard errors of the mean. These 40 samples were evenly distributed over the paddocks and it was recorded when the sample was taken in a dung patch. These soil cores were stored at $-20^{\circ} \mathrm{C}$ until washing. Soil was washed away with water, and root mass was collected as carefully as possible. With this procedure losses of root mass are minimal at about $20 \%$ (Floris \& de Jager, 1981). No attempts were made to count root number or to separate live and dead roots. Number of tillers of the cores was counted in 1981.

The roots were dried at $100{ }^{\circ} \mathrm{C}$ and weighed and bulked per layer per field. Bulk samples were ground at $1 \mathrm{~mm}$ and analysed for organic-matter content.

\section{Results}

\section{Sampling errors}

Variation in measured root masses of cores of the size used are normally rather large. In this programme coefficients of variation of dry root mass of single cores ranged from about 20 to $50 \%$ without any specific pattern. This means that with 40 samples per field least significant difference per field (grazing system) and sampling date range from about 9 to $22 \%$ of the mean values. A rather safe significant difference is assumed to be $20 \%$ in these trials.

\section{Experiment 1980}

Fig. 1 presents the changes in root mass during the summer of 1980 and the winter of $1980 / 81$ in the two grazing systems. Root mass was about 4.5 tonnes organic matter at the start of the grazing trial. It changed little under rotational grazing during the season, except for some increase during winter. Under continuous grazing, root mass increased appreciably during the early season and always remained higher than under rotational grazing. However, there was some reduction later on which may be ascribed to a greater decomposition of dead roots in the moist and warm soil of summer. Higher yields in April 1981 may have been caused by net root production in March.

Grazing system had little effect on the vertical distribution of the roots in the soil (Table 1). In both systems about $85 \%$ of the root mass was found in the top $10 \mathrm{~cm}$, similar to other findings (e.g. Klapp, 1954). Total root mass was less in the long grass of the dung patches, than in the shorter grass between the dung patches, especially in the top layer (Table 2). However, in the lower layers somewhat more root mass was found in dung patches. 


\section{B. DEINUM}

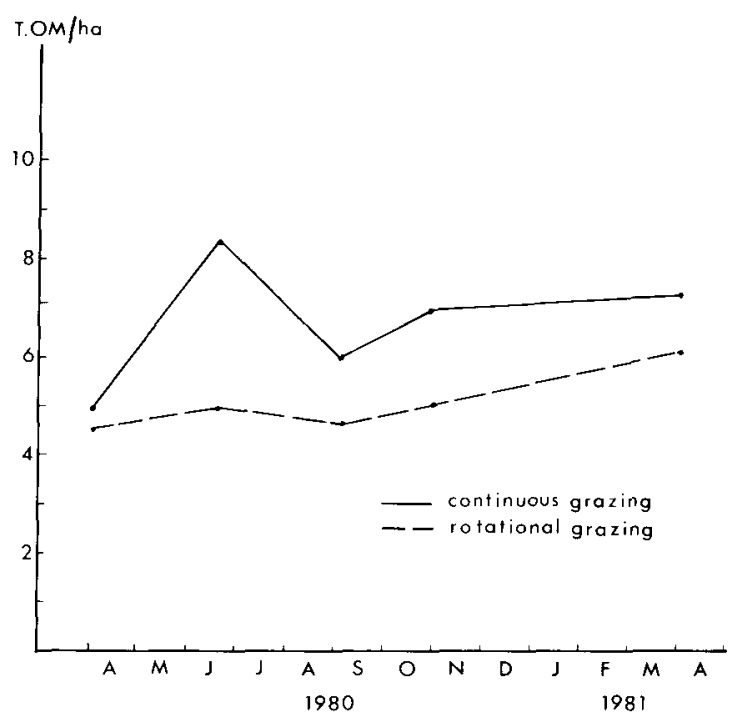

Fig. 1. Course of root mass (tonnes organic matter per ha in the top $30 \mathrm{~cm}$ of the soil) during the season of 1980 of grass swards under continuous and rotational grazing.

Table 1. Yield of root mass (tonnes organic matter per ha) in the different layers of the soil (average of 18 June, 3 September and 28 October 1980).

\begin{tabular}{lllll}
\hline & $0-10 \mathrm{~cm}$ & $10-20 \mathrm{~cm}$ & $20-30 \mathrm{~cm}$ & Total \\
Continuous grazing & $5.86(83 \%)$ & 0.82 & 0.40 & 7.08 \\
Rotational grazing & $4.14(85 \%)$ & 0.45 & 0.25 & 4.84 \\
\hline
\end{tabular}

Table 2. Yield of root mass (tonnes organic matter per ha) between and in dung patches in the different layers of the soil (average of 18 June, 3 September and 28 October 1980).

\begin{tabular}{|c|c|c|c|c|c|c|}
\hline & \multicolumn{3}{|c|}{ Dung patches } & \multicolumn{3}{|c|}{ Short grass } \\
\hline & $0-10 \mathrm{~cm}$ & $10-20 \mathrm{~cm}$ & $20-30 \mathrm{~cm}$ & $0-10 \mathrm{~cm}$ & $10-20 \mathrm{~cm}$ & $\begin{array}{l}20-30 \\
\mathrm{~cm}\end{array}$ \\
\hline Continuous grazing & 4.57 & 0.78 & 0.45 & 7.99 & 0.82 & 0.39 \\
\hline Rotational grazing & 3.86 & 0.47 & 0.31 & 4.20 & 0.44 & 0.19 \\
\hline
\end{tabular}

\section{Experiment 1981}

It was hypothesized that the results of the trial of 1980 might be ascribed partly to tillering. Therefore the trial was repeated in 1981 on a separate field and the counting of number of tillers on the soil cores was included.

Fig. 2 shows the root masses and numbers of tillers during the summer of 1981 and the winter of $1981 / 82$. Root mass was about 5.5 tonnes organic matter per ha at 


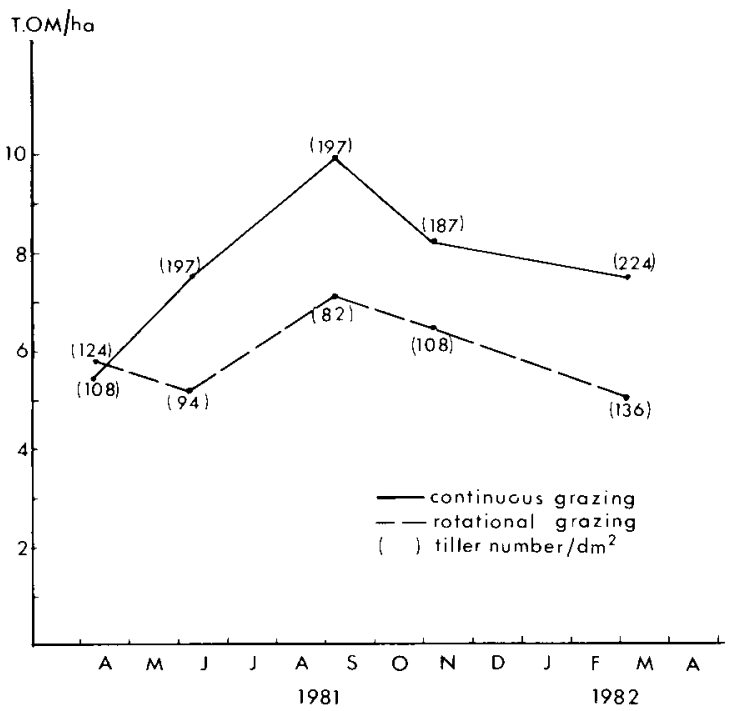

Fig. 2. Course of root mass (tonnes organic matter per ha in the top $30 \mathrm{~cm}$ of the soil) and of tiller density (numbers per $\mathrm{dm}^{2}$ ) during the season of 1981 of grass swards under continuous and rotational grazing.

Table 3. Yield of root mass per layer (tonnes organic matter per ha) in the different layers of the soil (average of 11 June, 3 September and 5 November 1981).

\begin{tabular}{lllll}
\hline & $0-10 \mathrm{~cm}$ & $10-20 \mathrm{~cm}$ & $20-30 \mathrm{~cm}$ & Total \\
Continuous grazing & $7.25(85 \%)$ & 0.76 & 0.54 & 8.55 \\
Rotational grazing & $5.01(81 \%)$ & 0.70 & 0.49 & 6.20 \\
\hline
\end{tabular}

Table 4. Yield of root mass (tonnes organic matter per ha) and number of tillers per $\mathrm{dm}^{2}$ in and between dung patches in the different layers of the soil (average of 11 June, 3 September and 5 November 1985).

\begin{tabular}{|c|c|c|c|c|c|c|c|c|}
\hline & \multicolumn{4}{|c|}{ Dung patches } & \multicolumn{4}{|c|}{ Short grass } \\
\hline & $\begin{array}{l}\text { tillers } \\
\text { per } \\
\mathrm{dm}^{2}\end{array}$ & $\begin{array}{l}0-10 \\
\mathrm{~cm}\end{array}$ & $\begin{array}{l}10-20 \\
\mathrm{~cm}\end{array}$ & $\begin{array}{l}20-30 \\
\mathrm{~cm}\end{array}$ & $\begin{array}{l}\text { tillers } \\
\text { per } \\
\mathrm{dm}^{2}\end{array}$ & $\begin{array}{l}0-10 \\
\mathrm{~cm}\end{array}$ & $\begin{array}{l}10-20 \\
\mathrm{~cm}\end{array}$ & $\begin{array}{l}20-30 \\
\mathrm{~cm}\end{array}$ \\
\hline Contin & 144 & 7.18 & 0.68 & 0.49 & 210 & 7.31 & 0.78 & 0.55 \\
\hline Rotational grazing & 79 & 4.44 & 0.63 & 0.36 & 100 & 5.03 & 0.71 & 0.52 \\
\hline
\end{tabular}

the start of the trial in April. It showed some decline and rise during the season under rotational grazing. There was a great increase in root mass under continuous grazing as in 1980, reaching a top in September after a dry July and August. Even after the winter there was still a great root mass compared to rotational grazing. These much greater root masses under continuous grazing could be associated very well with the greater number of tillers. 
Distribution of root mass over the 3 layers was not affected much by grazing system, although relative yield in the top layer of the continuously grazed dense sward tended to be somewhat higher (Table 3). Root mass under dung patches was slightly smaller than between dung patches, although not significantly so and was associated with the smaller tiller numbers (Table 4). On average about $20 \%$ of the samples came from dung patches.

\section{Discussion}

\section{Physiology of root and tiller production}

In his studies on photosynthesis and production of grazed swards, E. A. Lantinga (1981, personal communication) found a greater root mass with lower nitrogen fertilization and with continuous grazing. This was also correlated with a greater number of tillers.

Many other workers have found different seasonal patterns of root yield and different effects of defoliation. Behaeghe (1985, personal communication) found smaller or similar root mass under continuous grazing compared to rotational grazing dependent on grazing intensity. In the following an attempt will be made to explain the results of the various experiments.

It is obvious that tillering plays an important role. Many trials (Davidson, 1978; Garwood, 1966; Klapp, 1954) showed increased root production in early spring and autumn. Production was low in late spring and early summer, associated with stem elongation and adverse summer conditions. Such patterns are found under cutting and under rotational grazing with rather long intervals of harvesting. There is little tillering under such conditions, especially in spring during the reproductive phase.

Normally tall tillers dominate over small tillers, and many small ones die, but under proper conditions of continuous grazing these taller tillers cannot dominate because of their lax defoliation. Then few tillers succumb and many more can develop. Then root mass may increase like in our system of continuous grazing. Similarly when in spring elongating stems are decapitated by frequent grazing or cutting they loose their dominance and assimilates normally used for the stems can be used now for tillering and rooting. This function of elongation of stems became evident in a trial in which vernalized plants of $L$. perenne showed great tillering and root production when elongation was inhibited by short photoperiod in spring (Deinum, 1984). In addition, many trials show that frequent severe defoliations reduce root mass appreciably, presumably because the available reserve carbohydrates are mainly used to restore the shoot (= regrowth) and the original shoot/root ratio (Davidson, 1978; Ennik et al., 1980).

Extrapolating this information to grazing management, it may be postulated that in modern, intensive rotational grazing, defoliation is frequent and complete, whereas in modern continuous grazing small parts of the foliage are removed periodically, enabling improved tillering and rooting.

Therefore it may be concluded that all kinds of patterns in tiller and root production may be found in practice and that these patterns are almost entirely due to the grasses involved and to the management systems imposed to the grass sward. 


\section{Kinetics of production and decay of roots}

The yields presented are the sum of the white and brown living roots and of the dead root mass still present after the washing procedure. Live and dead roots can be damaged by soil-borne animals like insects and by micro-organisms. This decay will be at its best when the conditions for these organisms are at its best: optimal temperature, a good supply of oxygen, water and nutrients, optimal pH (Davidson, 1978; Klapp, 1954). Different organisms will have different requirements for these factors, but it may be expected that decay will be highest in warm soils with adequate oxygen and water. So the relatively low root mass on 3 September 1980 may be associated with the warm moist soil in July and August and the high yield on 3 September 1981 with the warm dry soil in these months.

Unfortunately detailed data on production and decay of root mass of grass swards are still lacking. Parsons et al. (1983) assumed that about $10 \%$ of gross photosynthesis is translocated to the roots for maintenance and growth. This seems too little as it would imply that $50 \mathrm{~kg}\left(\mathrm{CH}_{2} \mathrm{O}\right)$ per ha per day would be allocated for root production on sunny days in a closed canopy when assimilation rates of $500 \mathrm{~kg}$ $\left(\mathrm{CH}_{2} \mathrm{O}\right)$ per ha per day are measured. The open canopies under continuous grazing in 1980 and 1981 already produced $30-40 \mathrm{~kg}$ root mass per ha per day (net, i.e. production of new roots minus decomposition).

Translocation of $100 \mathrm{~kg}\left(\mathrm{CH}_{2} \mathrm{O}\right)$ per ha per day from normal canopies to the root zone would seem more realistic (C.T. de Wit, personal communication).

When one assumes a canopy of $L$. perenne with an average of 100 tillers per $\mathrm{dm}^{2}$ under ordinary grazing conditions with a live organic root mass of $4500 \mathrm{~kg}$ per ha (of which $20 \%$ is lost in the washing procedure) and a maintenance respiration of $1.5 \%$ of the live root mass per day at $15{ }^{\circ} \mathrm{C}$, it follows that for a season of 200 days a maintenance respiration of about 10 tonnes $\left(\mathrm{CH}_{2} \mathrm{O}\right)$ per ha is needed. When the turn-over rate of root mass is $1 / 2$ a year and the production respiration is $25 \%$, then 6.6 tonnes $\left(\mathrm{CH}_{2} \mathrm{O}\right)$ per ha is necessary for a production of 4.5 tonnes root organic matter per ha in 200 days. This makes a total of about 16.5 tonnes $\left(\mathrm{CH}_{2} \mathrm{O}\right)$ per ha. This is $27.5 \%$ of the gross photosynthesis of a well managed healthy sward and similar to the value Overgaard Mogensen (1977) found in respiration measurements. Since most of this respiration and production happens in the 200 days of the growing season, on an average about $80 \mathrm{~kg}\left(\mathrm{CH}_{2} \mathrm{O}\right)$ per ha must be translocated daily to the root zone. With increased tillering it can be even more.

Such calculations also suggest that in steady-state conditions $4500 \mathrm{~kg}$ per ha organic root mass is decomposed in such period i.e. some $20-25 \mathrm{~kg} \mathrm{ha}^{-1} \mathrm{day}^{-1}$ on average. This implies that under optimum soil conditions easily $50 \mathrm{~kg}$ root mass per ha can be decomposed daily (Fig. 1) and in bad conditions almost nothing.

\section{Some practical implications}

Our results suggest that the management of the grass sward has a great impact on its functioning. It is not difficult to stimulate herbage growth at the expense of tillering and root formation, which as a consequence induces bad regrowth and sward deterioration. On the other hand, management systems that stimulate tillering and rooting provide excellent swards for the future at the expense of present herbage yield. 


\section{B. DEINUM}

It is to the farmer to select to optimum for his persistency.

Tillering and rooting also have their consequences for soil organic matter. When sward density and rooting can be kept high, for example by proper continuous grazing more organic matter (mainly decomposed stubble and root) can accumulate in the soil. Then more nitrogen is accumulated in the organic matter and consequently the nitrogen economy of such a soil may deviate from that in a soil under a grass sward that is stimulated to maximum herbage production.

\section{Acknowledgement}

The help of Mr G. Besselink and co-workers in the sampling and washing procedures is gratefully acknowledged.

\section{References}

Brouwer, R., 1962. Nutritive influences on the distribution of dry matter in the plant. Netherlands Journal of Agricultural Science 20: 149-175.

Davidson, R. L., 1978. Root systems - the forgotten component of pastures. In: J. R. Wilson (Ed.), Plant relations in pastures. Proceedings Symposium CSIRO, Brisbrane: 86-94.

Davies, A.G., A. Troughton \& R. G. Simons 1974. Tillering and persistency in ryegrass. Welsh Plant Breeding Station, Annual Report 1984: 42.

Deinum, B., M. L. 't Hart \& E. A. Lantinga, 1981. Photosynthesis of grass swards under rotational and continuous grazing. Proceedings 14th International Grassland Congress, Lexington, Ky: 407-410.

Deinum, B., 1985. The effect of vernalization on the production physiology of Lolium perenne. Proceedings 15th International Grassland Congress, Kyoto (in press).

Ennik, G. C., M. Gillet \& L. Sibma, 1980. Effect of high nitrogen supply on sward deterioration and root mass. In: The role of nitrogen in intensive grassland production. Proceedings International Symposium European Grassland Federation: 67-76 Pudoc, Wageningen.

Ernst, P., Y. L. P. le Du \& L. Carlier, 1980. Animal and sward production under rotational and continuous grazing management; a critical appraisal. In: The role of nitrogen in intensive grassland production. Proceedings International Symposium European Grassland Federation: 119-126. Pudoc, Wageningen.

Floris, J. \& A. de Jager, 1981. Een schatting van het verlies aan droge stof en van de verandering in diameter van wortels van Engels raaigras (Lolium perenne) door bemonsteren, bewaren en spoelen. Rapport Instituut voor Bodemvruchtbaarheid, Haren 1-81, 18 pp.

Garwood, E. A., 1966. Studies on the roots of grasses. Grassland Research Institute, Hurley, Annual Report 1966: 72-79.

Klapp, E., 1954. Wiesen und Weiden, p. 67-80. Parey, Berlin.

Lantinga, E. A., 1985. Productivity of grasslands under continuous and rotational grazing. Doctoral thesis, Wageningen, $111 \mathrm{pp}$.

Overgaard Mogensen, V., 1977. Field measurements of dark respiration rates of roots and aerial parts in Italian ryegrass and barley. Journal of Applied Ecology, 14: 243-252.

Parsons, A. J., E. L. Laefe, B. Collett, P. D. Penning \& J. Lewis, 1983. The physiology and grass production under grazing. II. Photosynthesis, crop growth and animal intake of continuously grazed swards. Journal of Applied Ecology, 20: 127-139.

Troughton, A., 1957. The underground organs of herbage grasses. Commenwealth Agricultural Bureau, Hurley, Bull. 44, $163 \mathrm{pp}$.

Troughton, A., 1978. The influence of reproductive development upon the root system of perennial ryegrass and some effects upon herbage production. Journal of Agricultural Science, Cambridge. 91: 427431 .

Troughton, A., 1981. Length of life of grass root. Grass and Forage Science, 3: 117-120. 